(C) Сікора В.В., 2019 p.

https://orcid.org/0000-0002-9907-643X

DOI: $10.34142 / 23128046.2019 .47 .10$

B.B. Сікора

\title{
ІНТЕРАКТИВНА КОМПЕТЕНТНІСТЬ МАЙБУТНІХ УЧИТЕЛІВ ФІЗИЧНОЇ КУЛЬТУРИ: ПЕДАГОГІЧНІ УМОВИ ЇЇ ФОРМУВАННЯ
}

У статті аналізується актуальна проблема визначення педагогічних умов формування інтерактивної компетентності у прочесі навчання майбутніх учителів фізичної культури. Мета роботи - обтрунтування однієї із педагогічних умов формування інтерактивної компетентності майбутнього вчителя фізичної культури. Завдання роботи: розкрити педагогічну умову формування інтерактивної компетентності майбутнього вчителя; окреслити шляхи ї̈ реалізації. Для досягнення мети, розв'язання окреслених завдань дослідження було використано загальнонаукові методи теоретичного рівня: аналіз, синтез $і$ систематизачія праць авторів із проблеми дослідження щьоо підготовки вчителя фізичної культури; логікосистемний, проблемно-иільовий, порівняльний аналіз з метою теоретичного обтрунтування однієї із педагогічних умов формування інтерактивної компетентності майбутнього вчителя фізичної культури. Результатами дослідження є формулювання й обтрунтування однієї із педагогічних умов формування інтерактивної компетентності майбутніх учителів фізичної культури в процесі навчання. Це - впровадження інтерактивних тактик $i$ стратегій навчання, спрямованих на формування інтерактивної компетентності майбутнього вчителя фізичної культури, що забезпечується реалізацією спектру інтерактивних ролей майбутнього вчителя (контролер, режисер, менеджер, фасілітатор, порадник, спікер, модератор, тренер, координатор, новатор); впровадженням інтерактивних стилів викладання (вчительський, змістовий, учнівський, взаємодійний, навчально-особистісний); співпрачею та партнерством викладача $i$ студента з урахуванням інтерактивних методів навчання. Зроблено висновок про те, щзо проведене дослідження підкреслює необхідність переходу від традииійного до інтерактивного навчання, оновлення тактик $i$ стратегій навчання, інтерактивних ролей, стилів, методів зі студентами у закладах вищої освіти.

Ключові слова: інтерактивна компетентність, майбутній учитель фізичної культури, педагогічна умова, інтерактивні тактики і стратегії навчання, інтерактивні ролі вчителя, інтерактивні стилі викладання.

Sikora V.V. Interactive competence of future teachers of physical training: pedagogical conditions of its development.The manuscript analyzes the actual 
problem of defining pedagogical conditions when forming interactive competence in the training process of future teachers of physical training. The purpose of the research is to substantiate one of the pedagogical conditions for forming interactive competence of a future teacher of physical training. The tasks of the research are to investigate the pedagogical condition of forming interactive competence of a future teacher; to outline the ways of its implementation. To achieve the goal, to solve the outlined tasks of the research we used the general scientific theoretical methods: analysis, synthesis and systematization of the authors' manuscripts on the research problem of learning teachers of physical training; logical and systemic, problem-oriented, comparative analysis with the purpose of theoretical substantiation of one of the pedagogical conditions of forming interactive competence of a future teacher of physical training. The results of the research are the formulation and justification of one of the pedagogical conditions for forming interactive competence of future teachers of physical training in the learning process. This pedagogical condition is the introduction of interactive tactics and training strategies aimed at forming interactive competence of a future teacher of physical training. It is ensured by the implementation of the spectrum of interactive roles for a future teacher (checker, director, manager, facilitator, advisor, speaker, moderator, trainer, coordinator); as well as by the introduction of interactive teaching styles (teacher's style, content style, student's style, interactive, educational and personal styles). It is ensured by collaboration and partnership between teachers and students, taking into account interactive teaching methods. We conclude that the research emphasizes the need to move from traditional to interactive learning, updating teaching tactics and strategies, interactive roles, styles, methods with students at Universities.

Keywords: interactive competence, future teacher of physical training, pedagogical condition, interactive tactics and learning strategies, interactive teacher's roles, interactive teaching styles.

Вступ. Сучасний рівень розвитку суспільства, освіти та науки висуває високі вимоги до компетентності фахівців різних напрямів, що потребує суттєвих змін у процесі навчання, зокрема навчання майбутніх учителів фізичної культури. У законотворчих документах (Національна стратегія розвитку освіти в Україні на 2012-2021 рр., Закон України «Про вищу освіту», Закон України «Про фізичну культуру і спорт», Концепція загальнодержавної цільової соціальної програми розвитку фізичної культури і спорту на 2012-2016 pp. та ін.) увиразнено нові вимоги до навчання фахівців у галузі фізичної культури.

Навчання майбутніх учителів фізичної культури в закладах вищої освіти нерозривно пов'язано зі змістом їхньої майбутньої професійної діяльності. Таке навчання характеризується регламентацією навчальних планів і програм, значною кількістю обов'язкових аудиторних занять, однак, 
на жаль, іноді таке навчання визначає відсутність ефективної взаємодії (інтеракції) викладачів і студентів. Це гальмує формування інтерактивної компетентності студентів.

У межах проведеного дослідження заслуговує на особливу увагу твердження про те, що створення певних педагогічних умов уможливлює ефективне формування інтерактивної компетентності майбутнього вчителя фізичної культури в процесі навчання.

У педагогічній науці умови формування інтерактивної компетентності майбутніх учителів фізичної культури є тим питанням, яке ще не знайшло достатнього теоретичного обгрунтування й експериментальної перевірки. Недостатнє дослідження цієї проблеми спонукає нас до визначення педагогічних умов формування інтерактивної компетентності у процесі навчання майбутніх учителів фізичної культури.

Деякі аспекти навчання майбутніх учителів фізичної культури розроблялися Ю. Драгнєвим (Drahniev, 2014), Т. Матвійчук (Matviichuk, 2015), Л. Сущенко (Sushchenko, 2004), О. Тимошенко (Tymoshenko, 2009), Б. Шияном (Shyian, 1997) та ін.

Проведений аналіз науково-методичної літератури 3 проблеми навчання майбутніх учителів фізичної культури надає змогу стверджувати, що педагогічні умови вимагають комплексної реалізації у процесі широкомасштабного дослідження. Проте, у попередніх дослідженнях не виокремлено педагогічних умов формуванням інтерактивної компетентності майбутніх учителів фізичної культури.

Мета та завдання статті - обгрунтування однієї із педагогічних умов формування інтерактивної компетентності майбутнього вчителя фізичної культури. Завдання: розкрити педагогічну умову формування інтерактивної компетентності майбутнього вчителя; окреслити шляхи їі реалізації.

Методи дослідження. Для досягнення мети, розв'язання окреслених завдань дослідження було використано загальнонаукові методи теоретичного рівня: аналіз, синтез і систематизація праць авторів із проблеми дослідження щодо підготовки вчителя фізичної культури; логіко-системний, проблемноцільовий, порівняльний аналіз з метою теоретичного обгрунтування однієї із педагогічних умов формування інтерактивної компетентності майбутнього вчителя фізичної культури.

Результати. Аналіз тенденцій розвитку вищої освіти, теоретикометодичних праць сучасних дослідників і власного досвіду викладацької діяльності дозволив нам сформулювати й обгрунтувати одну із педагогічних умов формування інтерактивної компетентності майбутніх учителів фізичної культури в процесі навчання. Це - впровадження інтерактивних тактик $i$ 
стратегій навчання, спрямованих на формування інтерактивної компетентності майбутнього вчителя фізичної культури, що забезпечується реалізацією спектру інтерактивних ролей майбутнього вчителя (контролер, режисер, менеджер, фасілітатор, порадник, спікер, модератор, тренер, координатор, новатор); впровадженням інтерактивних стилів викладання (вчительський, змістовий, учнівський, взаємодійний, навчальноособистісний); співпрацею та партнерством викладача i студента 3 урахуванням інтерактивних методів навчання.

У результаті проведених попередніх досліджень нами визначено суть поняття «формування інтерактивної компетентності майбутніх учителів фізичної культури» як здатність здійснювати студентом міжособистісну взаємодію та інтеракцію на заняттях і в реальному житті; спроможність студента активізувати інтерактивну діяльність (Kostikova, 2018) 3 викладачами та учнями під час виконання будь-якого завдання в межах міжсуб'єктної взаємодії; готовність студента до застосування інтерактивних методів, прийомів, форм і засобів навчання студентів (Sikora, 2018).

Безумовно, важливим аспектом для реалізації педагогічної умови впровадження інтерактивних тактик і стратегій навчання є реалізація спектру інтерактивних ролей майбутнього вчителя. Закордонний дослідник Д. Браун (Brown, 2007) вивчає і систематизує перелік ролей вчителя/викладача, які є основою успішного процесу інтерактивного навчання, а саме: учительконтролер, учитель-режисер, учитель-менеджер, учитель-фасилітатор, учитель-порадник (табл.1).

Таблиця 1

\section{Інтерактивні підходи в педагогіці}

\begin{tabular}{|c|c|c|}
\hline Автор & Класифікація & Зміст ролі \\
\hline \multirow{7}{*}{ Дуглас Браун } & учитель-контролер & організація сприятливої атмосфери \\
\cline { 2 - 3 } & учитель-режисер & $\begin{array}{c}\text { створення навчальної ситуації, подібної до } \\
\text { реального життя }\end{array}$ \\
\cline { 2 - 3 } & учитель-менеджер & $\begin{array}{c}\text { чітке планування кожного етапу/блоку } \\
\text { освітнього процесу }\end{array}$ \\
\cline { 2 - 3 } & учитель-фасилітатор & $\begin{array}{c}\text { мотивація до самостійного пізнання інформації } \\
\text { і здобуття нових знань }\end{array}$ \\
\cline { 2 - 3 } & учитель-порадник & $\begin{array}{c}\text { допомога порадами на потребу учнів у } \\
\text { вирішенні складних задач }\end{array}$ \\
\hline
\end{tabular}




\section{Інтерактивні ролі вчителя}

\begin{tabular}{|c|c|c|}
\hline \multirow{6}{*}{$\begin{array}{l}\text { Джейсон С. Ренч, } \\
\text { Вірджинія Річмонд, }\end{array}$} & учитель-спікер & $\begin{array}{c}\text { виклад навчального матеріалу у формі } \\
\text { лекції, адресованої великій групі слухачів }\end{array}$ \\
\hline & учитель-модератор & $\begin{array}{c}\text { регуляція дискусії або диспуту; аналіз і } \\
\text { діагностика досягнутих результатів }\end{array}$ \\
\hline & учитель-тренер & $\begin{array}{c}\text { мотивація студентів до успішного } \\
\text { виконання навчальної діяльності }\end{array}$ \\
\hline & учитель-менеджер & $\begin{array}{c}\text { визначення завдань і часу на їх виконання; } \\
\text { надання допомоги студентам під час } \\
\text { роботи }\end{array}$ \\
\hline & учитель-координатор & $\begin{array}{c}\text { відбір друкованих, електронних, аудіо-, } \\
\text { відеоресурсів для оптимізації процесу } \\
\text { навчання }\end{array}$ \\
\hline & учитель-новатор & $\begin{array}{c}\text { розробка та впровадження інноваційних } \\
\text { технологій навчання }\end{array}$ \\
\hline
\end{tabular}

Доповнюють та розширюють попередне визначення Дж. С. Ренч, В. Річмонд, Дж. Гохем (Wrench, Richmond \& Gorham, 2001) (табл.2).

Безумовно, реалізація інтерактивних ролей вчителя логічно пов'язана 3 впровадженням інтерактивних стилів викладання. Так, американські вчені Б. Фішер та Л. Фішер називають інтерактивні стилі викладання базовими засадами реалізації особистісної взаємодії і пропонують наступні п'ять стилів інтерактивного викладання: 1) стиль, спрямований на вчителя (вчительський); 2) стиль, спрямований на зміст (змістовий); 3) стиль, спрямований на учня (учнівський); 4) стиль, спрямований на взаємодію між вчителем і учнем (взаємодійний); 5) стиль, спрямований на зміст навчання і на особистість учня (навчально-особистісний) (Fischer \& Fischer, 1979).

Визначення інтерактивних ролей i стилів майбутнього вчителя допомагає розкрити основу співпраці викладачів і студентів 3 урахуванням інтерактивних форм, методів, методичних прийомів, засобів. Стрижневими компонентами у цьому контексті $є$ інтерактивні методи навчання.

Г. Коберник пропонує інтерактивним вважати метод, у якому той, хто навчається, $є$ учасником і виконавцем: говорить, керує, моделює, пише, вирисовує тощо; тобто, не виступає тільки слухачем, спостерігачем, а бере активну участь у тому, що відбувається (Kobernyk, 2007).

M. Скрипник, яка також вивчає інтерактивні методи навчання, визначає їх як систему способів взаємодії суб'єктів навчання, що спрямовані на осмислення змісту навчання. Інтерактивні методи навчання М. Скрипник поділяє на інформаційні, пізнавальні, мотиваційні й регулятивні методи (Skrypnyk, 2005). 
Інформаційні інтерактивні методи - це способи діалогічної взаємодії учасників навчання, які впроваджуються 3 метою обміну цінностями (матеріальними або духовними). Прикладами є такі методи: «Моє ім'я», «Перше знайомство», «Хвилина мого життя», «Паперові літаки», «Мандруємо разом», «Іменні жетони».

Пізнавальні інтерактивні методи - це способи пізнавальної взаємодії учасників, які використовуються 3 метою отримання і систематизації нових знань, творчого вдосконалення фахових умінь і навичок. До цієї групи методів належать: «Від А до Я», «Ділова гра», «Мозкова атака», «Екскурсія».

Мотиваційні інтерактивні методи - це способи діалогічної взаємодії учасників навчального процесу, які допомагають визначити власну позицію кожного щодо діяльності групи, окремих учнів, викладача та самого себе. До мотиваційних інтерактивних методів належать: «Моє очікування», «Лист до самого себе», «Самооцінка», «3:2:1».

Регулятивні інтерактивні методи - це способи встановлення i прийняття правил діалогічної взаємодії учасників навчання. До них належать такі методи: «Виробимо правила», «Порахуємо разом» (рис.1.).

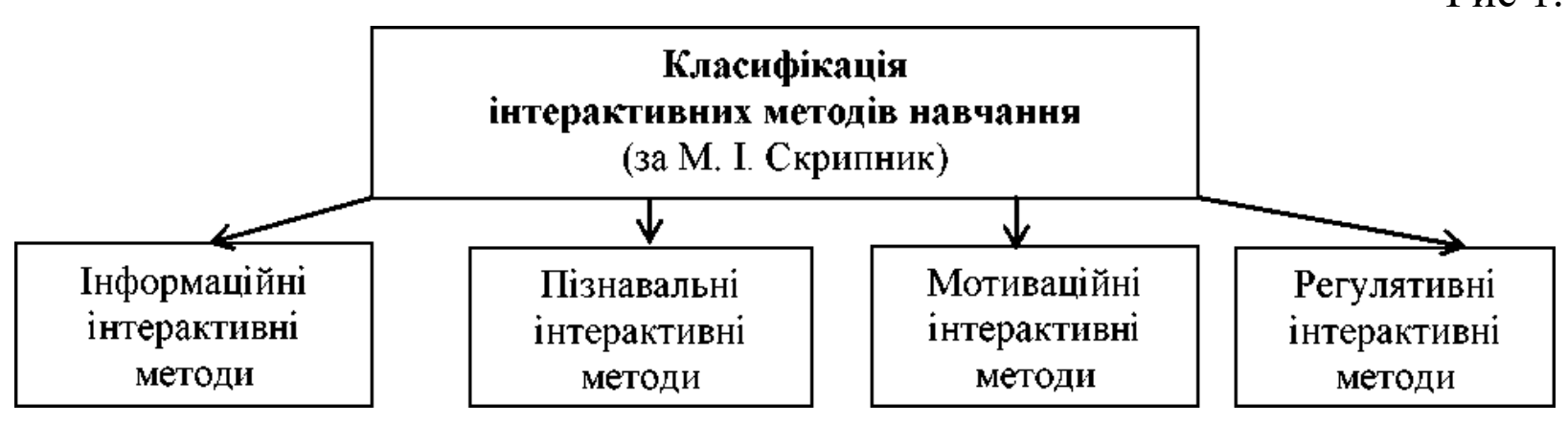

Безперечно, інтерактивні методи навчання полягають в імітації інтерактивних видів діяльності згідно 3 навчальними цілями. В їх основу покладено прийом моделювання ситуації, відпрацювання і прийняття рішень в умовах здійснення діяльності. Можна визначити наступні цілі впровадження інтерактивних методів навчання: отримання і оцінювання інформації; участь в обговоренні інформації; співпраця з іншими учасниками взаємодії з метою досягнення означених цілей.

Разом із визначеними цілями, $є$ можливість виокремити головні завдання інтерактивних методів, які полягають у формуванні професійно значущих умінь і навичок. Це вміння: сформувати власну позицію щодо вирішення фахових питань; вміння приймати рішення щодо суперечних питань; вміння відстоювати власну думку. Це навички: інтелектуальні навички, які передбачають розвиток логічного і критичного мислення; 
комунікативні навички, які забезпечують формування й чітке пояснення власного погляду; навички взаємодії і спільної діяльності у групі.

До найбільш ефективних інтерактивних методів навчання вчена зараховує: метод проблемного пояснення, презентація, дискусія, кейс-стаді, робота в групі, метод мозкового штурму, метод критичного мислення, вікторини, міні-дослідження, ділові ігри, рольові ігри, метод бліцопитування, метод анкетування, прийом «Бінго».

Отже, обгрунтування однієї із педагогічних умов формування інтерактивної компетентності майбутніх учителів фізичної культури в процесі навчання - впровадження інтерактивних тактик і стратегій навчання - сприятиме іiі реалізації через визначені нами шляхи.

Обговорення. Проведене дослідження i аналіз упровадження інтерактивних тактик і стратегій підтверджує погляди як зарубіжних учених (Д. Браун, Дж. С. Ренч, В. Річмонд, Дж. Гохем, Б. Фішер та Л. Фішер), так і вітчизняних (Г. Коберник, М. Скрипник), що сучасне навчання майбутніх фахівців значною мірою характеризується тенденцією переходу від традиційного до інтерактивного навчання.

Так, можна визначити, що аналіз отриманих нами даних співпадає 3 результатами досліджень попередників. Іншими словами, проведене дослідження підтверджує висновки інших науковців щодо необхідності переходу від традиційного до інтерактивного навчання, оновлення тактик i стратегій навчання, інтерактивних ролей, стилів, методів при роботі зі студентами у закладах вищої освіти.

Висновки. Отже, ретельний аналіз науково-практичного досвіду вітчизняних та зарубіжних науковців у контексті галузі формування інтерактивної компетентності та власні спостереження у процесі викладання уможливили формулювання наступних висновків: ефективне формування інтерактивної компетентності вимагає дотримання педагогічних умов, одна із яких є впровадження інтерактивних тактик і стратегій навчання.

Реалізація педагогічної умови при формуванні інтерактивної компетентності майбутнього вчителя фізичної культури передбачає впровадження спектру інтерактивних ролей майбутнього вчителя (контролер, режисер, менеджер, фасілітатор, порадник, спікер, модератор, тренер, координатор, новатор); введення інтерактивних стилів викладання (вчительський, змістовий, учнівський, взаємодійний, навчальноособистісний); урахування інтерактивних методів навчання. Перспективи подальших розвідок у даному напрямі полягають у визначенні інших педагогічних умов формування інтерактивної компетентності майбутнього вчителя фізичної культури. 
ЛІТЕРАТУРА:

Драгнєв Ю. В. Професійний розвиток майбутнього вчителя фізичної культури: теоретикометодичний аспект. Education and pedagogical sciences. 2014. № 1. С. 38-43. Режим доступу: http://nbuv.gov.ua/UJRN/OsDon_2014_1_6.

Коберник Г. I. Формування толерантності молодих школярів у процесі інтерактивних технологій навчання. Збірник наукових пращь Уманського державного педагогічного університету імені Павла Тичини. Умань : РВЦ «Софія», 2007. С. 104-112.

Костікова I. I. Інтерактивність майбутнього фахівця як якість навчання і риса особистості. Матеріали конференції «Психологічні та педагогічні проблеми професійної освіти та патріотичного виховання персоналу системи МВС України». Х. : ХНУВС, 2018. С. 45-47. Режим http://univd.edu.ua/general/publishing/konf/30_03_2018/pdf/12.pdf

Матвійчук Т. Ф. Модель формування педагогічної майстерності майбутніх учителів фізичної культури у процесі професійної підготовки. Педагогічні аспекти професійної підготовки майбутнього фахівия з фізичного виховання та спорту. № 129. Том II. 2015. C. 208-212.

Сікора В. В. Використання методів інтерактивного навчання майбутніх учителів фізичної культури при викладанні предметів циклу професійної підготовки. Вісник Чернігівського начіонального педагогічного університету імені Т.Г.Шевченка. Серія: Педагогічні науки. Фізичне виховання та спорт. - Чернігов, № 154 (2), 2018. С. 69-73. Режим доступу: http://dspace.hnpu.edu.ua/bitstream/123456789/2376/1/\%d0\%a1\%d1\%96\%d0\%ba\%d0\% be\%d1\%80\%d0\%b0\%20\%d0\%92.\%20\%d0\%92.\%20.pdf

Сікора В.В. Шляхи формування інтерактивної компетентності майбутніх учителів фізичної культури в освітньому процесі. Матеріали VIII Всеукраїнської науковопрактичної конференції «Педагогіка здоров'я». Х. 2018. С. 611-614. Режим доступу: http://hnpu.edu.ua/sites/default/files/files/Kaf_zdor_ta_korr_os/Pedag_zdor_2018.pdf

Скрипник М. I. Інтерактивне навчання: основні поняття. Ігри дорослих. Інтерактивні методи навчання. Бібліотека «Шкільного світу». Київ : «Редакція загально педагогічних газет». 2005. 96 с.

Сущенко Л. П. Теоретико-методологічні засади професійної підготовки майбутніх фахівців фізичного виховання та спорту у вищих навчальних закладах: автореф. дис... докт. пед. наук: 13.00.04. К., 2004. 45 с.

Тимошенко О. В. Теоретико-методичні засади оптимізації професійної підготовки вчителів фізичної культури у вищих навчальних закладах : автореф. дис. ... докт. пед. наук : 13.00.04. К., 2009. 38 с.

Шиян Б. М. Теоретико-методичні основи підготовки вчителів фізичного виховання в педагогічних закладах : автореф. дис. на здобуття наук. ступеня д-ра пед. наук : спец. 13.00.04. К., 1997. 48 с.

Brown, D. (2007). Teaching by Principles: An Interactive Approach to Language Pedagogy. 3rd ed. Pearson Education ESL. 569 p.

Fischer, B., \& Fischer, L. (1979). Styles in teaching \& learning. Educational Leadership, 36, 245-254.

Wrench, J. S., Richmond, V. P., Gorham, J. Communication Affect \& Learning in the Classroom. 2nd ed. Tapestry Press, MA. USA, 2001. 227 p.

\section{REFERENCES:}

Drahniev, Yu. V. (2014). Profesiinyi rozvytok maibutnoho vchytelia fizychnoi kultury: teoretyko-metodychnyi aspekt [Professional development of a future teacher of physical 
training: theoretical and methodical aspect]. Education and pedagogical sciences. 1, 3843. Retrieved from: http://nbuv.gov.ua/UJRN/OsDon_2014_1_6. (in Ukrainian).

Kobernyk, H. I. (2007). Formuvannia tolerantnosti molodykh shkoliariv u protsesi interaktyvnykh tekhnolohii navchannia [Formation of young students' tolerance in the process of interactive learning technologies]. Zbirnyk naukovykh prats Umanskoho derzhavnoho pedahohichnoho universytetu imeni Pavla Tychyny. Uman: RVTs «Sofiia», 104-112. (in Ukrainian).

Kostikova, I.I. (2018). Interaktyvnist maibutnoho fakhivtsia yak yakist navchannia i rysa osobystosti [Interactivity of the future specialist as a training quality and as a personal trait]. Materialy konferentsii „Psykholohichni ta pedahohichni problemy profesiinoi osvity ta patriotychnoho vykhovannia personalu systemy MVS Ukrainy". Kharkiv: KhNUVS, 45-47. Retrieved from: http://univd.edu.ua/general/publishing/konf/30_03_2018/pdf/12.pdf (in Ukrainian).

Matviichuk, T. F. (2015). Model formuvannia pedahohichnoi maisternosti maibutnikh uchyteliv fizychnoi kultury u protsesi profesiinoi pidhotovky. [Model of forming pedagogical skills for future teachers of physical training in the process of vocational training]. Pedahohichni aspekty profesiinoi pidhotovky maibutnoho fakhivtsia $\mathrm{z}$ fizychnoho vykhovannia ta sportu. 129 (II), 208-212. (in Ukrainian).

Sikora, V. V. (2018). Vykorystannia metodiv interaktyvnoho navchannia maibutnikh uchyteliv fizychnoi kultury pry vykladanni predmetiv tsyklu profesiinoi pidhotovky. [Using methods of interactive training for future teachers of physical training in teaching subjects of professional training]. Visnyk Chernihivskoho natsionalnoho pedahohichnoho universytetu imeni T.H.Shevchenka. Seriia: Pedahohichni nauky. Fizychne vykhovannia ta sport. Chernihov, 154 (2), 69-73. Retrieved from: http://dspace.hnpu.edu.ua/bitstream/123456789/2376/1/\%d0\%a1\%d1\%96\%d0\%ba\%d0\% be\%d1\%80\%d0\%b0\%20\%d0\%92.\%20\%d0\%92.\%20.pdf (in Ukrainian).

Sikora, V. V. (2018). Shliakhy formuvannia interaktyvnoi kompetentnosti maibutnikh uchyteliv fizychnoi kultury $\mathrm{v}$ osvitnomu protsesi. [Ways of forming interactive competence for future teachers of physical training in the educational process]. Materialy VIII Vseukrainskoi naukovo-praktychnoi konferentsii «Pedahohika zdorovia». Kharkiv, 611$614 . \quad$ Retrieved from: http://hnpu.edu.ua/sites/default/files/files/Kaf_zdor_ta_korr_os/Pedag_zdor_2018.pdf (in Ukrainian).

Skrypnyk, M. I. (2005). Interaktyvne navchannia: osnovni poniattia. [Interactive learning: basic concepts]. Ihry doroslykh. Interaktyvni metody navchannia. Biblioteka «Shkilnoho svitu». Kyiv: «Redaktsiia zahalno pedahohichnykh hazet». 96 p. (in Ukrainian).

Sushchenko, L. P. (2004). Teoretyko-metodolohichni zasady profesiinoi pidhotovky maibutnikh fakhivtsiv fizychnoho vykhovannia ta sportu u vyshchykh navchalnykh zakladakh. [Theoretical and methodological principles of professional training for future specialists of physical training and sports in higher educational establishments]. (Abstract of candidate's thesis). Kyiv, Ukraine. (in Ukrainian).

Tymoshenko, O. V. (2009). Teoretyko-metodychni zasady optymizatsii profesiinoi pidhotovky vchyteliv fizychnoi kultury u vyshchykh navchalnykh zakladakh. [Theoretical and methodological principles of optimizing professional training for teachers of physical training in higher educational establishment]. (Abstract of Doctor's thesis). Kyiv, Ukraine. (in Ukrainian).

Shyian, B. M. (1997). Teoretyko-metodychni osnovy pidhotovky vchyteliv fizychnoho vykhovannia $\mathrm{v}$ pedahohichnykh zakladakh. [Theoretical and methodological foundations for teachers of physical training in pedagogical institutions]. (Abstract of Doctor's thesis). Kyiv, Ukraine. (in Ukrainian).

Brown, D. (2007). Teaching by Principles: An Interactive Approach to Language Pedagogy. 3rd ed. Pearson Education ESL. 569 p. 
Fischer, B., \& Fischer, L. (1979). Styles in teaching \& learning. Educational Leadership, 36, 245-254.

Wrench, J. S., Richmond, V. P. \& Gorham, J. (2001) Communication Affect \& Learning in the Classroom. 2nd ed. Tapestry Press, MA. USA, 227 p.

\section{Інформація про автора:}

Сікора Валерія Валеріївна:

ORCID: $\quad$ https://orcid.org/0000-0002-9907643X; аспірантка кафедри загальної педагогіки i педагогіки вищої школи Харківського національного педагогічного університету імені Г.С. Сковороди, м. Харків, Україна, вул. Валентинівська, 2, 61000

e-mail: kaf_pedagogik@ukr.net
Information about the author: Sikora Valeriia Valeriivna:

ORCID: https://orcid.org/0000-0002-9907643X; Ph.D. Candidate of the Department of General Pedagogy and Pedagogy of Higher School, H.S. Skovoroda Kharkiv National Pedagogical University, Kharkiv, Ukraine, , Street Valentynivska, 2, 61000

e-mail: kaf_pedagogik@ukr.net

Цитуйте цю статтю як: Сікора В. В. Інтерактивна компетентність майбутніх учителів фізичної культури: педагогічні умови іiї формування. Теорія та методика навчання та виховання. 2019. № 47. С. 113-122.

DOI: $10.34142 / 23128046.2019 .47 .10$

Дата надходження статті до редакції: 27.09.2019

Стаття прийнята до друку: 08.10.2019 